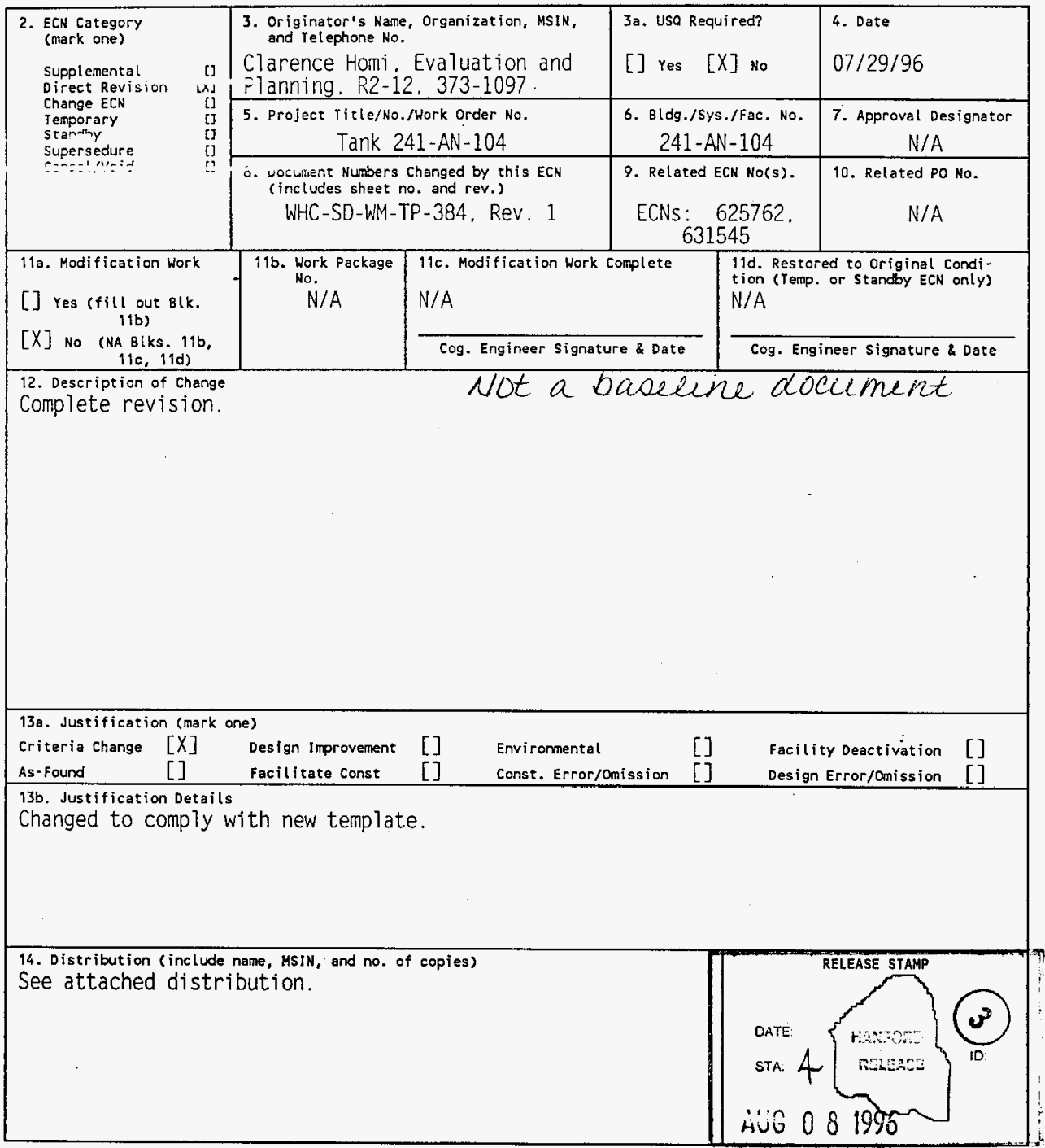




\section{ENGINEERING CHANGE NOTICE}

- ECN (use no. from pg. ")

ECN-635303

\begin{tabular}{|c|c|c|c|c|c|}
\hline \multirow{4}{*}{$\begin{array}{l}\text { 15. Design } \\
\text { Verification } \\
\text { Required } \\
{[] \text { Yes }} \\
{[X] \text { No }}\end{array}$} & \multicolumn{4}{|c|}{ 16. Cost Impact } & \multirow[t]{2}{*}{ 17, schedule I mpact } \\
\hline & & & & & \\
\hline & Additional & $\$$ & Additional & $\$$ & Improvenent \\
\hline & Savings & $\$$ & Savings & $\$$ & De.ay \\
\hline
\end{tabular}

18. Change Impact Review: Indicate the related documents (other than this engineering doctments ident $i f i e d$ on side 1 ) that will be affected by the change described in Block 12 . Enter th: affected document number in Block 19. SDD/DD

Functional Design Criteria

[] Seismic/Stress Analysis

[] Stress/Design Report

Operating Specification

Criticality Specification

Conceprual Design Report

[]

Interface Control Drawing

[]

[]

Tark Calibration Manual

Equipment Spec.

[]

Calibration Procedure

[]

Health Physics Procedure

Installation Procedure

[]

Spares Multiple Unit Listing

[]

Maintenance Procedure

[]

Test Procedures/Specification

Component Index

ASME Coded Item

Const. Spec

Engineering Procedure

[]

Procurement Spec.

Vendor Information

[]

Operating Instruction

[]

Human Factor Consideration

[] Operating Instruction

[]

Computer Software

Operational Safety Requirement

[]

OM Manual

FSAR/SAR

Safety Equipment List

IEFD Drawing

[]

Cell Arrangement Drawing

[]

Radiation Work Permit

[]

Essential Material Specification

Environmental Impact Statement

Fac. Proc. Samp. Schedule

[]

Inspection Plan

[]

Electric Circuit Schedule

Environmental Report

inventory Adjustment Request

[]

ICAS Procedure

Process Control Manual/Plan

Process Flow Chart

Purchase Requisition

Environmental Permit

19. Other Affected Documents: (NOTE: Documents listed below will not be revised by this ECN.) Signatures below indicate that the signing organization has been notified of other affected documents listed below. Document Number/Revision Document Number/Revision

Document Number Revision N/A

20. Approvals

signature

OPERATIONS AND ENGINEERWNG

Cog. Eng. c.s. Homi C fta.

Cog. Mgr. J.W. Hunts

Safety

Environ.

Other W.D. Winkelman

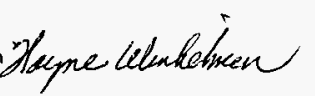

Signature

ARCHI TECT -ENG INEER

PE

OA

Safety

Design

Environ.

other

\section{DEPARTMENT OF ENERGY}

Signature or a Control Number that

tracks the Approval signature

ADDIYIONAL
Date 


\section{Tank 241-AN-104 Tank Characterization Plan}

\section{Clarence S. Homi}

Westinghouse Hanford Company. Richland. WA 99352

U.S. Department of Energy Contract DE-AC06-87RL10930

$\begin{array}{lll}\text { EDT/ECN: } & \text { ECN-635303 } & \text { UC: } 2070 \\ \text { Org Code: } & 79200 & \text { Charge Code: N4G6A } \\ \text { B\&R Code: } & \text { EW } 3120074 & \text { Tota1 Pages: } 10\end{array}$

Key Words: Characterization. General Safety Issues. Specific Safety Issues, Information Requirements. Schedule

Abstract: This document is a plan that identifies the information needed to address relevant issues concerning short-term and long-term storage and long-term management of double-shell tank 241-AN-104.

TRADEMARK DISCLAIMER. Reference herein to any specific conmercial product, process, or service by tracle name, trademark, manufacturer, or otherwise, does not necessarily constitute or imply its endorsement, recomendation, or favoring by the United States Government or any agency thereof or its contractors or subcontractors.

Printed in the United States of America. To obtain copies of this document, contact: WHC/BCS Document Control Services, P.O. Box 1970, Mailstop H6-08, Richland HA 99352, Phone (509) 372-2420; Fax (509) 376-4989.
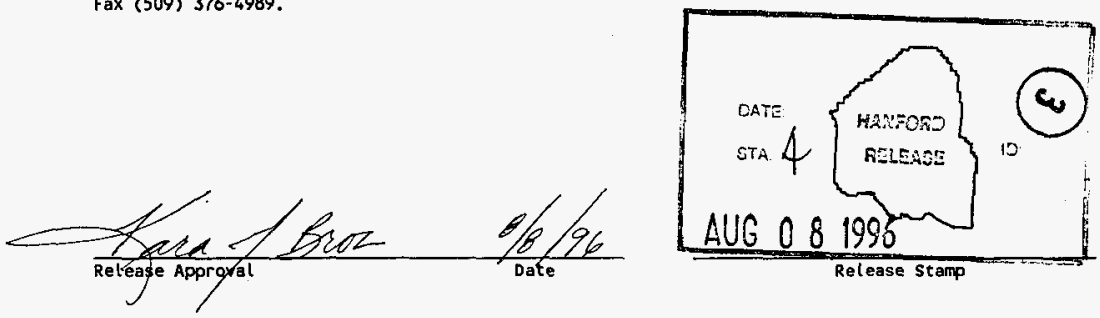

\section{Approved for Public Release}


(2) Title

TANK 241-AN-104 TANK CHARACTERIZATION PLAN

CHANGE CONTROL RECORD

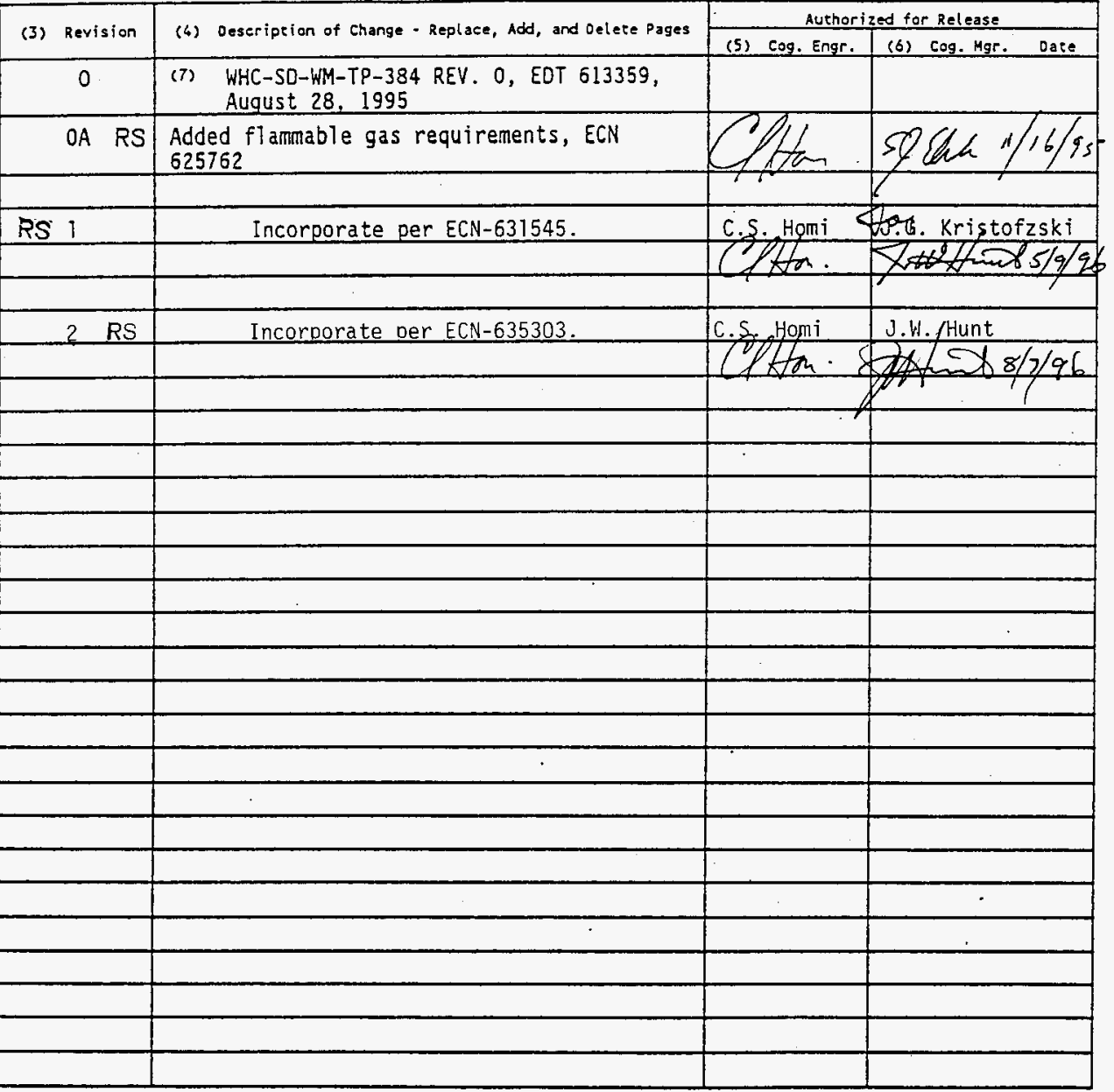




\title{
Tank 241-AN-104 Tank Characterization Plan
}

\author{
C. S. Homi
}

Westinghouse Hanford Company

Date Published

August 1996

Prepared for the U.S. Department of Energy Office of Environmental Restoration and Waste Management

\section{Q20 Westinghouse p.o. Box 190 Hanford Company Richand, washingon}

Management and Operations Contractor for the

U.S. Department of Energy under Contract DE-AC06-87RL10930 
WHC-SD-WM-TP-384, REV 2

TABLE OF CONTENTS

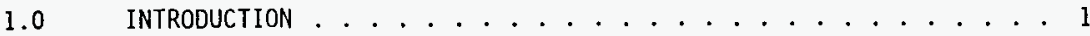

2.0 PROGRAM ELEMENTS REQUIRING INFORMATION FOR TANK 241-AN-104 . . . 1

2.1 GENERAL SAFETY ISSUES ............... 1

2.1.1 Safety Screening .............. 1

2.1.2 Vapor Safety Screening ............. 2

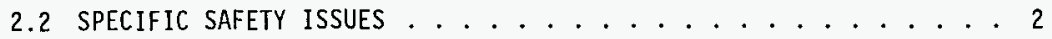

2.2.1 Ferrocyanide .................. 2

2.2.2 Organic Phenomenology ................ 2

2.2.3 Flammable Gas................... 2

2.2.4 Vapor Space Phenomenology ............... 2

2.2.5 Criticality.................. 2

2.2.6 High Heat Load . . . . . . . . . . . . . . . 2

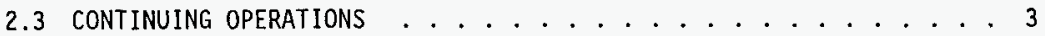

2.3.1 Compatibility/Stabilization ........... 3

2.3.2 Evaporator ................. 3

2.3.3 Caustic Mitigation ............. 3

2.4 DOUBLE-SHELL TANK WASTE ANALYSIS PLAN .......... 3

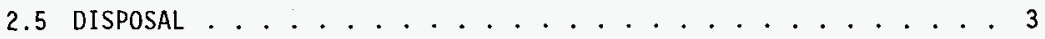

2.5.1 Retrieval ...................... 3

2.5.2 Process Testing................. 3

2.5.3 Privatization ............... 3

2.6 HISTORICAL MODEL EVALUATION . . . . . . . . . . . 3

3.0 HOW INFORMATION WILL BE OBTAINED ............... 4

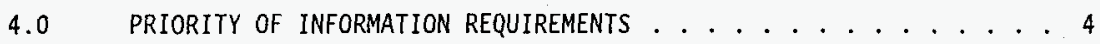

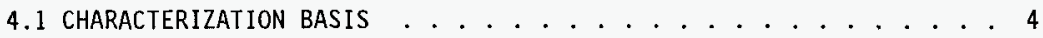

4.2 SAMPLING SCHEDULE . . . . . . . . . . . . . . 4

5.0 WHEN INFORMATION WILL BE AVAILABLE .......... 5

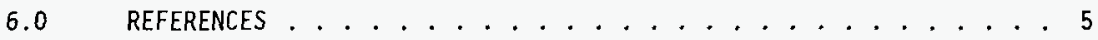

\section{LIST OF TABLES}

4-1 Integrated DQO Requirements and Priorities ........ 5 


\section{WHC-SD-WM-TP-384, REV 2}

\subsection{INTRODUCTION}

This Tank Characterization Plan (TCP) jdentifies the information needed to address issues related to short-term and long-term safe storage and long-term management of double shell tank 241-AN-104 (AN-104). It should be understood that needs and issues surrounding tank $A N-104$ are evolving as new information becomes available. As a result, this TCP addresses only issues that have been identified to date. It is expected that changes may be necessary as additional issues or needs arise which impact the management of tank AN-104. As necessary, this TCP will be revised to reflect changes. This plan reflects the best information available as of August 1996.

Tank AN-104 entered into service in September 1981. Waste was transferred from tank 241-AW-102 during the fourth quarter of 1982. The tank continued to receive non-complexed waste unt il November 1982 . The tank has contained doubleshe11 slurry feed waste from December 1982 until the present. During the fourth quarter of 1983, the tank also received low-level waste from Plutonium Uranium Extraction (PUREX). The tank has not received waste since the second quarter of 1985. The slight jevel changes are attributed to slurry growth as a result of gas generation. The tank is currently inactive and is considered a concentrated waste holding tank (Brevick et al. 1995).

This tank currently contains a total volume of $4013 \mathrm{~kL}$ (1060 kgal) of waste, which is equivalent to $979 \mathrm{~cm}$ (386 in) of waste as measured from the basel ine of the tank (Hanlon 1996).

Tank AN-104 is currently on the Flammable Gas Watch List.

Near-term sampling and analysis activities are focused on verifying or changing the Watch List tank status, and identifying any new safety issues. If new safety issues are identified, analysis activities consistent with the identified issue will be performed.

In addition to resolving safety issues, it is intended that all tank waste will be subject to pretreatment and retrieval to prepare it for final storage or disposal. Presently, these long-range plans are not yet fully identified and, therefore, are not included in this document.

\subsection{PROGRAM ELEMENTS REQUIRING INFORMATION FOR TANK 241-AN-104}

This section lists the Tank Waste Remediation System program elements and identifies those that require characterization data from tank AN-104.

\subsection{GENERAL SAFETY ISSUES}

\subsubsection{Safety Screening}

The Tank Safety Screening Data Quality Objective (Dukelow et al. 1995) describes the sampling and analytical requirements that are used to screen tank waste for unidentified safety issues. Analytical requirements for tank safety screening are energetics, total alpha activity, moisture content, density and flammable gas concentration. Based on the these analytical results, additional analysis may be performed. 


\subsubsection{Vapor Safety Screening}

Al1 177 underground tanks must be vapor-sampled for organic solvent screening in accordance with the Recommendation 93-5 Implementation P7an (DOE-RL 1996a). Organic solvent screening will be performed using the Scope Increase of "Data Quality Objective to Support Resolution of the Organic Complexant Safety Issue" Rev. 2 (Cash 1996b). The primary vapor analyses conducted will determine Total Non-methane Hydrocarbon content. All previous vapor samples were analyzed for Total Non-methane Hydrocarbon content.

\subsection{SPECIFIC SAFETY ISSUES}

\subsubsection{Ferrocyanide}

This tank is not on the Ferrocyanide Watch List; therefore, no information needs are currently identified for this program element.

\subsubsection{Organic Phenomenology}

Tank AN-104 is not on the Organic Watch List. It also has not been identified as in scope of the organic DQO by either the Data Quality Objective to Support Resolution of the Organic Complexant Safety Issue (Turner et a1. 1995) or the Scope Increase of "Data Quality Objective to Support Resolution of the Organic Complexant Safety Issue" Rev. 2 (Cash 1996b). Therefore, no information needs are currently identified for this program element.

\subsubsection{Flammable Gas}

Tank AN-104 has been identified as in scope of the Flammable Gas Safety Program: Data Requirements for Core Sample Analysis Developed through the Data Quality Objectives Process (McDuffie 1995) or the Application of "Flammable Gas Tank Safety Program: Data Requirements For Core Sampling Analysis Developed Through the Data Quality Objectives Process" Rev. 2 (Cash 1996a). The waste analyses conducted wi 71 determine both physical and chemical properties that may affect gas retention in the waste.

\subsubsection{Vapor Space Phenomenology} item.

No information needs from tank AN-104 have been identified for this program

\subsubsection{Criticality}

No information other than that for the general safety issue of tank AN-104 is currently identified for this program element. However, if the general safety screening of tank AN-104 identifies a potential criticality concern, analyses for fissile materials, and neutron sorbers and poisons will be performed as jdentified in the safety screening DQO (Dukelow et al. 1995).

\subsubsection{High Heat Load}

Tank AN-104 is not on the High Heat Watch List; therefore, no information needs are currently identified for this program element. 
WHC-SD-WM-TP-384, REV 2

2.3 CONTINUING OPERATIONS

\subsubsection{Compatibility/Stabilization}

This section does not apply to tank AN-104.

\subsubsection{Evaporator}

This section does not apply to tank AN-104.

\subsubsection{Caustic Mitigation} 1996).

The caustic concentration in tank $A N-104$ is within specification limits (WHC

\subsection{DOUBLE-SHELL TANK WASTE ANALYSIS PLAN}

Requirements for double-shell waste analyses are found in Double-Shell Tank Waste Analysis Plan (Mulkey and Jones 1995). This plan uses the compatibility (Fowler 1995) and safety screening (Dukelow et a1. 1995) DQOs as the basis for identifying data requirements and criteria for the safe storage and mixing of wastes.

\subsection{DISPOSAL}

\subsubsection{Retrieval}

Current retrieval needs (Bloom and Nguyen 1995) do not call for test samples to be taken from tank AN-104.

\subsubsection{Process Testing}

Tank AN-104 has been identified as a bounding tank for the pretreatment/disposal process development strategy (Kupfer et al. 1995). The strategy only requires that sample material be available from archive samples and does not require any specific analyses to be conducted on the samples.

\subsubsection{Privatization}

This section does not apply because tank AN-104 has not been chosen to represent a waste envelope as given in the TWRS Privatization Request for Proposal (RFP) (DOE-RL 1996b).

\subsection{HISTORICAL MODEL. EVALUATION}

This section does not apply because tank AN-104 is not identified as a primary or alternate bounding tank for historical model evaluations. 


\subsection{HOW INFORMATION WILL BE OBTAINED}

The number of samples required to characterize a tank is a function of waste heterogeneity and the desired confidence to make a correct decision. directed by the safety screening $\mathrm{DQO}$, if inadequate information exists to determine an appropriate number of samples, two vertical profiles will be obtained. These vertical profiles may be obtained using core, auger (for shallow tanks), or grab samples. If analysis of these profiles reveals that additional profiles are necessary to meet data needs, more sample profiles will be requested.

\subsection{PRIORITY OF INFORMATION REQUIREMENTS}

\subsection{Characterization Basis}

The priorities of all the tanks were determined by addressing safety, disposa1, and characterization issues in the Tank Waste Characterization Basis (Brown et al. 1996) document. The safety issues with their respective references are: flammable gas (McDuffie 1995, Cash 1996a), organic fuel phenomenology (Turner et a1. 1995, Cash 1996b), tank safety screening (Dukelow et a]. 1995), vapor screening (D0E-RL 1996a, Cash 1996b), vapor space phenomenology (DOE-RL 1996a) and ferrocyanide (Meacham et al. 1995). The disposal issues with their respective references are: privatization (Slankas and Kupfer 1995), process testing (Kupfer et al. 1995), and retrieval (Bloom and Nguyen 1995). The characterization issue with its respective reference is the historical model evaluation (Simpson and McCain 1996). These issues were ranked by priority in the Meeting Minutes of April 26 and 30, 1996 Meetings To Determine TWRS Issue Priorities (TWRS Technical Basis 1996).

Based on resultant priorities and sampling constraints, tank AN-104 is included in the list for sampling and analysis during FY 1996.

\subsection{Sampling Schedule}

Push mode core sampling is scheduled to begin July 1996. Vapor sampling is scheduled to begin in August 1998.

Refer to Table 4-1 for the current DQO requirements and planned sampling and analytical requirements. 
WHC-SD-WM-TP-384, REV 2

Table 4-1: Integrated DQO Requirements and Priorities

\begin{tabular}{|c|c|c|c|}
\hline $\begin{array}{l}\text { Sampling } \\
\text { Event }\end{array}$ & Applicable Issues & Sampling Requirements & Analytical Requirements ${ }^{*}$ \\
\hline $\begin{array}{l}\text { Vapor } \\
\text { Sampling }\end{array}$ & $\begin{array}{l}\text {-0rganic } \quad \text { Solvent } \\
\text { Screening } \\
\text { 1996a, Cash } 1996 \mathrm{~b} \text { ) }\end{array}$ & Steel canisters & Organic Vapors \\
\hline $\begin{array}{l}\text { Push Mode } \\
\text { Core } \\
\text { Sampling }\end{array}$ & $\begin{array}{l}\text {-Flammable Gas DQO } \\
\text {-Safety Screening DQO }\end{array}$ & $\begin{array}{l}\text { Core samples from } 2 \\
\text { risers separated } \\
\text { radially to the } \\
\text { maximum extent } \\
\text { possible } \\
\text { Combustible gas } \\
\text { measurement }\end{array}$ & $\begin{array}{l}\text { Flammability, Energetics, } \\
\text { Moisture, Total alpha } \\
\text { activity, Anions, } \\
\text { Cations, Radionuclides, } \\
\text { Density, Physical } \\
\text { properties, pH, Total } \\
\text { Organic Carbon, Total } \\
\text { Inorganic Carbon, Cr(VI). }\end{array}$ \\
\hline
\end{tabular}

* Consult each applicable DQO in force at the time for sampling and analytical requirements.

\subsection{WHEN INFORMATION WILL BE AVAILABLE}

According to the FY-97 TWAP Sampling Schedule (Stanton 1996), data are expected to be available from the push mode core sampling event for tank AN-104 in December 1996 and for vapor sampling in December 1998. This date may be altered if the sampling schedule changes.

\subsection{REFERENCES}

Bloom, G. R. and Q. H. Nguyen, 1995, Characterization Data Needs for Development, Design and Operation of Retrieval Equipment Developed Through the Data Quality Objective Process, WHC-SD-WM-DQ0-008, Rev. 0 , Westinghouse Hanford Company, Richland, Washington.

Brevick, C. H., L. A. Gaddis, and S. D. Consort, 1995, Supporting Document for Historical Tank Contents Estimate for AN-Tank Farm (Vol I and II), WHC-SD-WM-ER-314, Rev. 0, ICF Kaiser Hanford Company, Richland, Washington.

Brown, T. M., S. J. Eberlein, J. W. Hunt, and T. J. Kunthara, 1996, Tank Waste Characterization Basis, WHC-SD-WM-TA-164, Rev. 2, Westinghouse Hanford Company, Richland, Washington.

Cash, R. J., 1996a, Application of "Flammable Gas Tank Safety Program: Data Requirements For Core Sampling Analysis Developed Through the Data Quality Objectives Process" Rev. 2 (Internal Memo 79300-96-028, to S. J. Eberlein, July 12), Westinghouse Hanford Company, Richland, Washington. 
Cash, R. J., 1996b, Scope Increase of "Data Quality Objective to Support Resolution of the Organic Complexant Safety Issue" Rev. 2 (Internal Memo 79300-96-029, to S. J. Eberlein, July 12), Westinghouse Hanford Company, Richland, Washington.

D0E-RL, 1996a, Recommendation 93-5 Implementation Plan, D0E/RL-94-0001, Rev. 1, U.S. Department of Energy, Richland, Washington.

DOE-RL, 1996b, Request For Proposals (RFP) No. DE-RP06-96RL13308

[TWRS Privatization], U. S. Department of Energy, Richland, Washington.

Dukelow, G. T., J. W. Hunt, H. Babad, and J. E. Meacham, 1995, Tank Safety Screening Data Quality Objective, WHC-SD-WM-SP-004, Rev. 2, Westinghouse Hanford Company, Richland, Washington.

Fowler, K.D., 1995, Data Quality Objectives for Tank Farm Waste Compatibility Program, WHC-SD-WM-DQO-001, Rev. 1, Westinghouse Hanford Company, Richland, Washington.

Hanlon, B.M., 1996, Waste Tank Summary for Month Ending April 30, 1996 , WHC-EP-0182-97, Westinghouse Hanford Company, Richland, Washington.

Kupfer, M. J., W. W. Schultz, and J. T. Slankas, 1995, Strategy for Sampling Hanford Site Tank Wastes for Development of Disposal Technology,

McDuffie, N. G., 1995, Flammable Gas Tank Safety Program: Data Requirements for Core Sample Analysis Developed Through the Data Quality Objectives Process, WHC-SD-WM-DQO-004, Rev. 2, Westinghouse Hanford Company, Richland, Washington.

Meacham, J. E., R. J. Cash, B. A. Pulsipher, and G. Chen, 1995, Data Requirements for the Ferrocyanide Safety Issue Developed Through the Data Quality Objectives Process, WHC-SD-WM-DQ0-007, Rev. 2, Westinghouse Hanford Company, Richland, Washington.

Mulkey, C. H., and J. M. Jones, 1995, Doub7e-Shell Tank System Waste Ana7ysis Plan, WHC-SD-WM-EV-053, Rev 3, Westinghouse Hanford Company, Richland, Washington.

Simpson, B. C. and D. J. McCain, 1996, Historical Model Evaluation Data Requirements, WHC-SD-WM-DQ0-018, Rev. 1, Westinghouse Hanford Company, Richland, Washington.

Slankas, J. T. and M. J. Kupfer, 1995 Data Needs and Attendant Data Quality Objectives for Tank Waste Pretreatment and Disposal, WHC-SD-WMQQ0-022, Rev. 0, Westinghouse Hanford Company, Richland, Washington.

Stanton, G. A., 1996, Sampling Events for 40 Tanks Identified in the FY-97 TWAP (Internal Memo 75610-96-10, to C. S. Homi, July 26), Westinghouse Hanford Company, Richland, Washington.

Turner, D. A., H. Babad, L. L. Buckley and J. E. Meacham, 1995, Data Quality Objective to Support Resolution of the Organic Complexant Safety Issue, WHC-SD-WM-DQ0-006, Rev. 2, Westinghouse Hanford Company, Richl and, Washington. 
TWRS Technical Basis, 1996, Meeting Minutes of April 26 and 30, 1996 Meetings To Determine TWRS Issue Priorities, (Internal Memo 7900096-001 to R. F. Bacon, May 20), Westinghouse Hanford Company, Richland, Washington.

WHC, 1996, Operating Specifications for the 124-AN, $A P, A W, A Y$, $A Z$, \& SY Tank Farms, Rev. H-17, OSD-T-151-00007, Westinghouse Hanford Company, Richland, Washington. 


\begin{tabular}{|c|c|c|c|c|c|}
\hline \multirow{2}{*}{$\begin{array}{l}\text { To } \\
\text { Distribution }\end{array}$} & \multirow{2}{*}{\multicolumn{3}{|c|}{$\begin{array}{l}\text { From } \\
\text { Evaluation and Planning }\end{array}$}} & \multicolumn{2}{|l|}{ Page 1 of 1} \\
\hline & & & & \multicolumn{2}{|c|}{ Date $\quad 07 / 29 / 96$} \\
\hline \multicolumn{4}{|l|}{ Project Title/Work Order } & \multicolumn{2}{|c|}{ EDT No. N/A } \\
\hline \multicolumn{4}{|c|}{$\begin{array}{l}\text { WHC-SD-WM-TP-384, Rev. 2, "Tank 241-AN-104 Tank Characterization } \\
\text { Plan" }\end{array}$} & \multicolumn{2}{|c|}{ ECN No. ECN -635303} \\
\hline Name & MSIN & $\begin{array}{c}\text { Text } \\
\text { With } \\
\text { Al1 } \\
\text { Attach. }\end{array}$ & Text Only & $\begin{array}{l}\text { Attach.' } \\
\text { Appendix } \\
\text { Only }\end{array}$ & $\begin{array}{l}\text { EDT/ECN } \\
\text { Only }\end{array}$ \\
\hline
\end{tabular}

\section{ONSITE}

U. S. Department of Energy Richland Field Office

W. Liou

N. W. Willis

$\begin{array}{ll}\text { S7-54 } & x \\ 57-54 & x\end{array}$

Westinghouse Hanford Company

C. S. Homi

T. J. Kelley

W. D. Winkelman

Central Files

T.C.R.C.

$\begin{array}{ll}\text { R2 }-12 & x \\ \text { S7-21 } & x \\ \text { R2-12 } & x \\ \text { A3-88 } & x \\ \text { R2-12 } & x\end{array}$

\section{OFFSITE}

U. S. Department of Energy - Headquarters

office of Environmental Restoration and

Waste Management EM-563

12800 Middlebrook Road

Germantown. MD 20874

J. A. Poppiti

$x$ 